\title{
Ampicillin in the Treatment of Pneumonia
}

\section{A Cooperative Controlled Trial*}

Ampicillin is a broad-spectrum antibiotic effective against a number of micro-organisms causing pneumonia. It was therefore thought worth while to investigate its use in the treatment of this disease, comparing the results with previously accepted therapy. A combination of benzylpenicillin and streptomycin was adopted as the standard treatment for comparison. The possible advantage of this régime over penicillin alone lies in a greater effect on certain organisms such as Haemophilus influenzae. If ampicillin were as effective it would obviously be more useful for domiciliary treatment, as it is given orally.

The trial began in November 1962 and was continued until February 1965. Patients in the trial were also included in a wider investigation into the aetiology of pneumonia which began before November 1962 and is still continuing. This report, though making use of some of the available aetiological data, is confined to a comparison of the two methods of treatment.

\section{Methods}

\section{Type of Patient}

All patients admitted to hospital with a clinical diagnosis of pneumonia were included in the trial, with the exception of (a) those who were so ill on admission that they were in danger of dying within the first 24 hours and for whom intravenous therapy might prove necessary, and (b) those who were known to be hypersensitive to penicillin or streptomycin.

\section{Treatment Groups}

Selection of patients for the trial was made by the physician admitting the patient. In the first part of the trial (covering the first 51 patients) allocation to the treatment groups was made by opening the next of a series of sealed and numbered envelopes, inside which a card stated the treatment to be employed. A preliminary analysis of the first 51 cases showed that, by chance, there was an excess of mild cases and a deficiency of severe cases in the ampicillin group. Accordingly a modification of the method of allocation was adopted. The physician was asked to make a preliminary assessment of the severity of the patient's illness, classifying it as either (a) " mild" or (b) "moderate or severe." He then opened a large envelope labelled "mild" or " moderate or severe," which in turn contained a series of sealed and numbered envelopes as before. The treatment cards, however, were biased in favour of a mild case receiving penicillin and streptomycin, and a moderate or severe case receiving ampicillin. The physician was unaware of this bias.

The patients allotted to the ampicillin group were treated as follows: $250 \mathrm{mg}$. of ampicillin (Penbritin) was given orally

* The trial was carried out in the respiratory wards of the City Hospital (Professor J. W. Crofton, Drs. A. C. Douglas, N. W. Horne, J. D. Ross) and the Northern Gereral Hospital (Dr. I. W. B. Grant), Edinburgh. The laboratory work was carried out by Drs. Margaret A. Calder, Margaret A. J. Moffat, and Sheila M. Stewart at the Wellcome Laboratory, City Hospital, and by Drs. J. C. Gould and A. F. Maccabe at the Western General Hospital, Edinburgh. The trial was co-ordinated by Dr. Eileen C. Crofton, who prepared the report. on admission, and thereafter six-hourly for seven days. If at the end of this period the physician considered the patient's condition satisfactory the drug was discontinued, but, if not, a further seven days' treatment in similar dosage was given. The penicillin/streptomycin treatment group received on admission 1 mega unit of benzylpenicillin and $1 \mathrm{~g}$. of streptomycin sulphate by intramuscular injection. This was repeated twice daily for seven days. If the patient required further treatment the streptomycin was then stopped, but the penicillin was continued, 1 mega unit twice daily, for a further seven days. In each case 14 days was the length of the treatment allowed for in the protocol. A decision to prolong treatment beyond 14 days was left to the discretion of the physician. The clinician was asked to state his reasons if he gave a second week of treatment, prolonged treatment, beyond two weeks, or changed it at any stage. Treatment was to be changed only if there was clear evidence of clinical deterioration or if organisms isolated were resistant to the drug in use and were thought to be responsible for the pneumonia. A few patients in the penicillin/streptomycin group were given isoniazid in addition if there was any reason to suspect the possibility of active tuberculosis, in order to prevent the development of streptomycin-resistant mycobacteria.

\section{Investigations}

A chest radiograph was obtained as soon as possible after admission and repeated weekly as long as the patient was in hospital. If any consolidation was present on discharge the patient was re- $x$-rayed approximately two weeks, one month, and three months after discharge until maximum clearing had been achieved. Total and differential white blood cell counts were also done on admission.

Sputum and laryngeal swabs were sent for culture and mouse inoculation before treatment was begun in hospital. At the same time blood was taken for culture. Bacteriological examination was repeated on specimens of sputum on the second, ${ }^{1}$ fifth, and tenth days after admission. If sputum was not available, laryngeal swabs were taken. Sensitivity tests to a range of antibiotics, including the drugs in use, were carried out on all potential pathogens isolated, the disc-diffusion method and/ or resistance ratios being used. Complement-fixation tests were carried out wherever possible on serum obtained on admission, and at two to three weeks and six to eight weeks after admission. The following antigens were used: influenza $A, B$, and $C$; Sendai ; parainfluenza 1,2 , and 3 ; adenovirus ; respiratory syncytial virus ; psittacosis ; Coxiella (Rickettsia) burnetii, and Mycoplasma pneumoniae. For purposes of this paper only a fourfold rise of titre was accepted as evidence of viral or mycoplasmal infection.

\section{Patients Studied}

\section{Withdrawals}

If the initial diagnosis was not borne out by subsequent investigations the patient was withdrawn from the trial. These

\footnotetext{
${ }^{1}$ In this paper the day of admission is regarded as the first day.
} 
withdrawals included cases of cardiac failure, acute exacerbations of bronchitis without radiological changes, bronchial carcinoma, pulmonary infarction, uraemia, and atypical glandular fever. A few patients with pneumonia who, in error, were not treated according to protocol were also withdrawn.

Ninety-three patients were admitted to the ampicillin group and 78 to the penicillin/streptomycin group. The discrepancy in admissions to the two groups may be explained partly by the adjustment made in the method of allocation during the course of the trial and partly by the fact that many wards were involved. Each ward carried its own series of sealed envelopes, and not all of a series were used at the time admission to the trial ceased.

Fourteen patients were withdrawn from the ampicillin group because of an error in the initial diagnosis, and one patient because he was thought later to be too ill for oral therapy. Eight were withdrawn from the penicillin/streptomycin group on account of a mistaken diagnosis, and three because of an error in following the treatment protocol. Five patients who received their penicillin by mouth in the second week have not been withdrawn. One of these was put on anticoagulants and injections were thus contraindicated, but in the other four patients this change appears to have been made in error. Thus 145 patients remained under investigation, of whom 78 were treated with ampicillin and 67 with penicillin and streptomycin.

TABLE I.-Comparability of Treatment Groups

\begin{tabular}{|c|c|c|c|c|c|}
\hline & & & & $\begin{array}{l}\text { Ampicillin } \\
\text { (78 Cases) }\end{array}$ & $\begin{array}{c}\text { Penicillin/ } \\
\text { Streptomycin } \\
\text { (67 Cases) }\end{array}$ \\
\hline Sex & $\left\{\begin{array}{l}\text { Male . } \\
\text { Female }\end{array}\right.$ & $\because$ & $\because$ & $\begin{array}{l}46(59 \cdot 0 \%) \\
32(41 \cdot 0 \%)\end{array}$ & $\begin{array}{l}42(62.7 \%) \\
25(37.3 \%)\end{array}$ \\
\hline Age & $\left\{\begin{array}{l}\text { Average } \\
\text { Under } 50 \\
50-64 \\
65 \text { and over }\end{array}\right.$ & $\because$ & $\because$ & $\begin{array}{r}56.0 \text { years } \\
22(28 \cdot 2 \%) \\
34(43.6 \%) \\
22(28.2 \%)\end{array}$ & $\begin{array}{l}56 \cdot 0 \text { years } \\
17(25 \cdot 4 \%) \\
31(46 \cdot 3 \%) \\
19(28 \cdot 3 \%)\end{array}$ \\
\hline $\begin{array}{l}\text { Previous } \\
\text { attacks of } \\
\text { pneumonia }\end{array}$ & $\left\{\begin{array}{l}\text { None } \\
1-2 \quad \ldots \\
>2 \\
\text { Not known }\end{array}\right.$ & $\begin{array}{l}. \\
\because \\
.\end{array}$ & $\begin{array}{l}\cdots \\
\because \\
\cdots\end{array}$ & $\begin{array}{c}50(64.1 \%) \\
19(24.4 \%) \\
7(9.0 \%) \\
2(2.5 \%)\end{array}$ & $\begin{array}{c}37(55.2 \%) \\
19(28.4 \%) \\
8(11.9 \%) \\
3(4.5 \%)\end{array}$ \\
\hline $\begin{array}{c}\text { Previous } \\
\text { exacerbations } \\
\text { of bronchitis }\end{array}$ & $\left\{\begin{array}{l}\text { None } \\
1-2 \quad \ldots \\
>2 \\
\text { Not known }\end{array}\right.$ & $\begin{array}{l}. \\
\cdots \\
\cdots\end{array}$ & $\because$ & $\begin{array}{c}42(53.8 \%) \\
7(9.0 \%) \\
24(30.8 \%) \\
5(6.4 \%)\end{array}$ & $\begin{array}{c}31(46.2 \%) \\
4(6.0 \%) \\
29(43.3 \%) \\
3(4.5 \%)\end{array}$ \\
\hline $\begin{array}{l}\text { Prevalence } \\
\text { and severity } \\
\text { of chronic } \\
\text { bronchitis }\end{array}$ & $\left\{\begin{array}{l}\text { None } \\
\text { Mild } \\
\text { Moderate } \\
\text { Severe } \\
\text { Not known }\end{array}\right.$ & $\begin{array}{l}\ldots \\
\because \\
\because\end{array}$ & $\begin{array}{l}\because \\
\because \\
\therefore\end{array}$ & $\begin{array}{c}33(42 \cdot 3 \%) \\
23(29 \cdot 5 \%) \\
20(25 \cdot 6 \%) \\
2(2 \cdot 6 \%) \\
0\end{array}$ & $\begin{array}{c}26(38.8 \%) \\
18(26.9 \%) \\
16(23.9 \%) \\
5(7.4 \%) \\
2(3.0 \%)\end{array}$ \\
\hline $\begin{array}{l}\text { Days } \\
\text { of illness } \\
\text { before } \\
\text { admission }\end{array}$ & $\begin{cases}0-3 & \cdots \\
4-7 & \cdots \\
8-14 & \cdots \\
\text { Over } & \text { i4 } \\
\text { Not known }\end{cases}$ & $\begin{array}{l}\ldots \\
\because \\
\because \\
.\end{array}$ & $\begin{array}{l}\because \\
\because \\
\because\end{array}$ & $\begin{array}{c}37(47 \cdot 4 \%) \\
21(26.9 \%) \\
11(14 \cdot 1 \%) \\
7(9 \cdot 0 \%) \\
2(2 \cdot 6 \%)\end{array}$ & $\begin{array}{c}31(46.3 \%) \\
23(34.3 \%) \\
7(10.4 \%) \\
4(6.0 \%) \\
2(3.0 \%)\end{array}$ \\
\hline \multicolumn{3}{|c|}{$\begin{array}{l}\text { Chemotherapy before admission } \\
\text { Average initial leucocytosis }\end{array}$} & $\because$ & $\begin{array}{c}30(38.5 \%) \\
12,400\end{array}$ & $20(29.9 \%)$ \\
\hline $\begin{array}{l}\text { Severity of } \\
\text { illness on } \\
\text { admission }\end{array}$ & $\left\{\begin{array}{l}\text { Mild } \\
\text { Moderate } \\
\text { Severe }\end{array}\right.$ & $\begin{array}{l}\cdots \\
\cdots \\
.\end{array}$ & $\begin{array}{l}\because \\
\cdots \\
\cdots\end{array}$ & $\begin{array}{c}100 \cdot 7^{\circ} \text { F. }\left(38.2^{\circ} \text { C. }\right) \\
22(28.2 \%) \\
47(60.3 \%) \\
9(11.5 \%)\end{array}$ & $\begin{array}{c}100 \cdot 7^{\circ} \mathrm{F} .\left(38 \cdot 2^{\circ} \mathrm{C} .\right) \\
10(14.9 \%) \\
50(74.7 \%) \\
7(10.4 \%)\end{array}$ \\
\hline $\begin{array}{l}\text { Anatomical } \\
\text { distribution }\end{array}$ & $\left\{\begin{array}{l}\text { Lobar } \\
\text { Segmental } \\
\text { Lobular } \\
\text { Not known }\end{array}\right.$ & $\begin{array}{l}. \\
\because \\
\cdots\end{array}$ & $\begin{array}{l}\cdots \\
\cdots \\
\cdots\end{array}$ & $\begin{array}{c}27(34.6 \%) \\
34(43.6 \%) \\
16(20.5 \%) \\
1(1.3 \%)\end{array}$ & $\begin{array}{c}36(53.7 \%) \\
21(31.4 \%) \\
10(14.9 \%) \\
0\end{array}$ \\
\hline
\end{tabular}

\section{Comparability of Treatment Groups (Table I)}

The two groups were found to be comparable with regard to sex and age distribution and the number of previous attacks of pneumonia and exacerbations of bronchitis. The prevalence of chronic bronchitis and its severity in the opinion of the clinician were similar in the two groups. There was no significant difference between the groups in the time the patient had been ill before admission to hospital. More patients in the ampicillin group had received some chemotherapy before admission than in the penicillin/streptomycin group. No significant difference was seen in the degree of leucocytosis on admission or the peak temperature recorded during the course of the illness. There was a larger proportion of mild cases in the ampicillin group, but no difference in the proportion of severely ill cases. The classification of severity was made by the physician admitting the case, and was based on clinical opinion. The penicillin/streptomycin group contained the larger proportion of lobar pneumonias.

The frequency of other chest diseases and coincident illnesses was similar in the two groups. One patient in each group was found to have active pulmonary tuberculosis shortly after discharge from hospital.

Table II gives some data on the aetiology of the pneumonia. Little difference is shown apart from the fact that positive blood cultures were obtained from five patients in the penicillin/

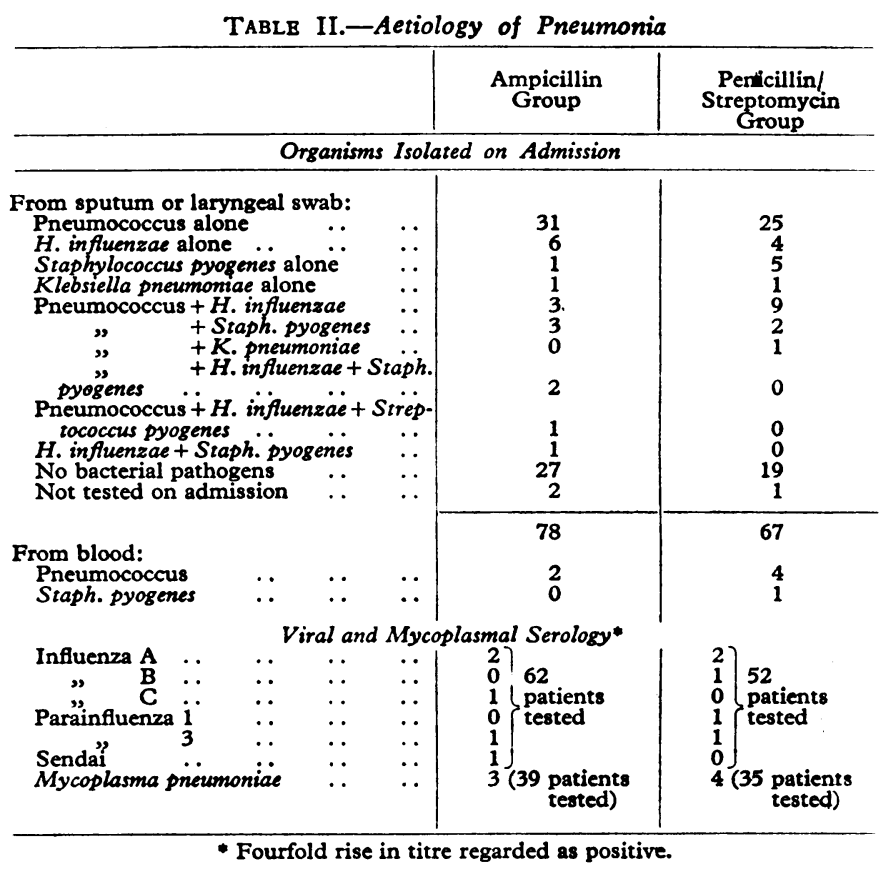

streptomycin group, compared with two patients in the ampicillin group. The higher proportion of patients in the ampicillin group in whom no organisms were isolated is probably a reflection of the greater use of antibiotics before admission to hospital.

Serological tests for viral infection were completed in 114 patients, and for infection with Myco. pneumoniae in 74 patients. The indications are that the proportion of positive results is very similar in the two groups.

A secondary infection was said to be present when a pathogen not found on admission was isolated on a subsequent occasion. Ten patients in the ampicillin group developed secondary infections-six with staphylococci, three with $H$. influenzae, and one with $K$. pneumoniae (Friedländer's bacillus). Eight patients receiving penicillin and streptomycin developed secondary infections-five staphylococcal and three due to $H$. influenzae.

\section{Results of Treatment}

Duration of Stay in Hospital.-The duration of stay in hospital was similar in the two groups, the average being 20 days for those treated with ampicillin and 22 days for those treated with penicillin and streptomycin.

Deaths.-Three patients in each treatment group died. In the ampicillin group two, aged 76 and 82 , died of pneumonia. The third death was due to hypoplastic anaemia, unrelated to treatment, 11 weeks after admission. Of the three deaths in the penicillin/streptomycin group one was probably due to myocardial infarction and one (in a woman of 77) to a sudden onset of ventricular fibrillation. The third death, in the seventh week, was due to right heart failure in a patient who also suffered from severe chronic bronchitis. 
Duration of Treatment.-Table III shows the total duration of antibiotic therapy received by the patients allotted to the two groups. It includes those patients who received a change of treatment. The slightly higher proportion of patients in the ampicillin group who received less than two weeks' treatment may be attributable to the higher proportion of mild cases in this group.

TABLE III.-Total Duration of Treatment

\begin{tabular}{|c|c|c|c|}
\hline & & $\underset{\text { Group }}{\text { Ampicillin }}$ & $\begin{array}{l}\text { Penicillin/ } \\
\text { Streptomycin Group }\end{array}$ \\
\hline $\begin{array}{l}\text { week } \ldots \\
\text { Between } 1 \text { and } 2 \text { weeks } \\
2 \text { weeks . } \\
\text { Over 2 weeks } \ldots \\
\text { Deaths within } 1 \text { week }\end{array}$ & 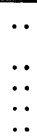 & $\begin{array}{c}30(38 \cdot 5 \%) \\
\text { (includes } 12 \text { mild cases) } \\
8(10 \cdot 2 \%) \\
27(34.6 \%) \\
11(14 \cdot 1 \%) \\
2(2.6 \%)\end{array}$ & $\begin{array}{c}22(32.8 \%) \\
\text { (includes } 5 \text { mild cases) } \\
4(6.0 \%) \\
25(37.3 \%) \\
15(22.4 \%) \\
1(1.5 \%)\end{array}$ \\
\hline
\end{tabular}

Change of Treatment.-In the ampicillin group treatment was changed in 10 cases before the 14 days' course was completed. The change was made on clinical grounds in seven cases and on bacteriological grounds in three. Eleven patients in the penicillin/streptomycin group had their treatment changed before the completion of the 14 days' course, but in two cases the only change of treatment involved was the administration of oral penicillin. The reasons given for the change were clinical in six patients and bacteriological in five.

Resolution of Temperature.-The first day of the permanent resolution of temperature was recorded. Fig. 1 shows that this occurred slightly earlier in the ampicillin group than in the penicillin/streptomycin group; $24.6 \%$ of the patients receiving ampicillin achieved resolution of temperature by the third day compared with $15.6 \%$ of the patients receiving penicillin and streptomycin. This difference is not statistically significant, and the ampicillin group contained a higher proportion of patients who were only mildly ill.

Clearance of Initial Pathogen.-Table IV shows the time taken for the organism found in the sputum or laryngeal swab on admission to disappear. There is no significant difference between the two groups.

TABLE IV.-Clearance of Initial Pathogens from Sputum

\begin{tabular}{|c|c|c|c|}
\hline $\begin{array}{l}\text { Clearance } \\
\text { Achieved }\end{array}$ & & $\begin{array}{l}\text { Ampicillin } \\
\text { Group }\end{array}$ & $\begin{array}{l}\text { Penicillin/ } \\
\text { Streptomycin Group }\end{array}$ \\
\hline 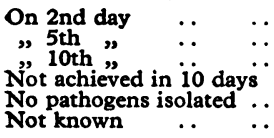 & $\begin{array}{l}. \\
\because \\
\because \\
\because\end{array}$ & $\begin{aligned} & 32(41 \cdot 0 \%) \\
& 12(15.4 \%) \\
& 2(2.6 \%) \\
& 2(2.6 \%) \\
& 27(34.6 \%) \\
& 3(3.8 \%)\end{aligned}$ & $\begin{array}{c}25(37.3 \%) \\
16(23.9 \%) \\
4(6.0 \%) \\
2(3.0 \%) \\
19(28.3 \%) \\
1(1.5 \%)\end{array}$ \\
\hline
\end{tabular}

\section{Maximum X-ray Clearing}

Table $\mathrm{V}$ shows the time in which maximum clearing was achieved. There is no significant difference between the two groups.

Three criteria of assessment-namely, resolution of temperature within seven days, clearance of the pathogen present on admission within two days, and maximum radiographic clearing within one month-were each examined separately in relation

TABLB V.-Maximum X-ray Clearing

\begin{tabular}{|c|c|c|}
\hline $\begin{array}{l}\text { Maximum Clearing } \\
\text { Achieved }\end{array}$ & $\begin{array}{c}\text { Ampicillin } \\
\text { Group }\end{array}$ & $\begin{array}{c}\text { Penicillin/ } \\
\text { Streptomycin Group }\end{array}$ \\
\hline $\begin{array}{l}\text { Within } 2 \text { weeks } \\
\text { After } 2 \text { weeks but within } 1 \text { month } \\
\text { Within } 1 \text { month }\end{array}$ & $\begin{array}{l}32(41 \cdot 0 \%) \\
10(12 \cdot 8 \%) \\
42(53.8 \%)\end{array}$ & $\begin{array}{l}23(34.3 \%) \\
16(23.9 \%) \\
39(58.2 \%)\end{array}$ \\
\hline 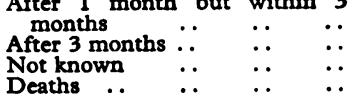 & $\begin{array}{l}22(28 \cdot 2 \%) \\
5(6.4 \%) \\
6(7 \cdot 7 \%) \\
3(3.9 \%)\end{array}$ & $\begin{array}{l}18(26.8 \%) \\
5(7.5 \%) \\
2(3.0 \%) \\
3(4.5 \%)\end{array}$ \\
\hline
\end{tabular}

to the various types of case. Factors investigated were the severity of the illness on admission, the peak temperature during the course of the illness, the initial total white-cell count, the anatomical distribution of the pneumonia, the days of illness before admission, the presence and severity of chronic bronchitis, the nature of the infecting organism, and the presence of secondary and virus infections. Some of the results are summarized in Table VI.

Although few differences reach statistically significant levels, the majority appear to favour the ampicillin group to some extent. Against this trend must be set the results in cases of segmental pneumonia. This group, however, contained only one severely ill patient, who was given penicillin and streptomycin, whereas four patients who were severely ill were allotted to the ampicillin group. The slower rate of radiological clearing in the lobar pneumonias treated by ampicillin cannot, however, be explained in the same way, nor is it due to a difference in the average age of the patients concerned.

The only difference of significance is represented in Fig. 2. In cases where the pneumococcus was the sole infecting organism the temperature became normal within seven days more frequently when the patient was given ampicillin than when he was given penicillin and streptomycin $\left(x^{2}=4.43 ; \mathrm{P}<0.05\right)$. This could, of course, be due to the greater proportion of mild cases in the ampicillin group. However, if the mild cases are excluded from the analysis, and only moderate or severe cases are included, the difference still remains statistically significant in favour of ampicillin $\left(\chi^{2}=4.45 ; \mathrm{P}<0.05\right)$. This result should

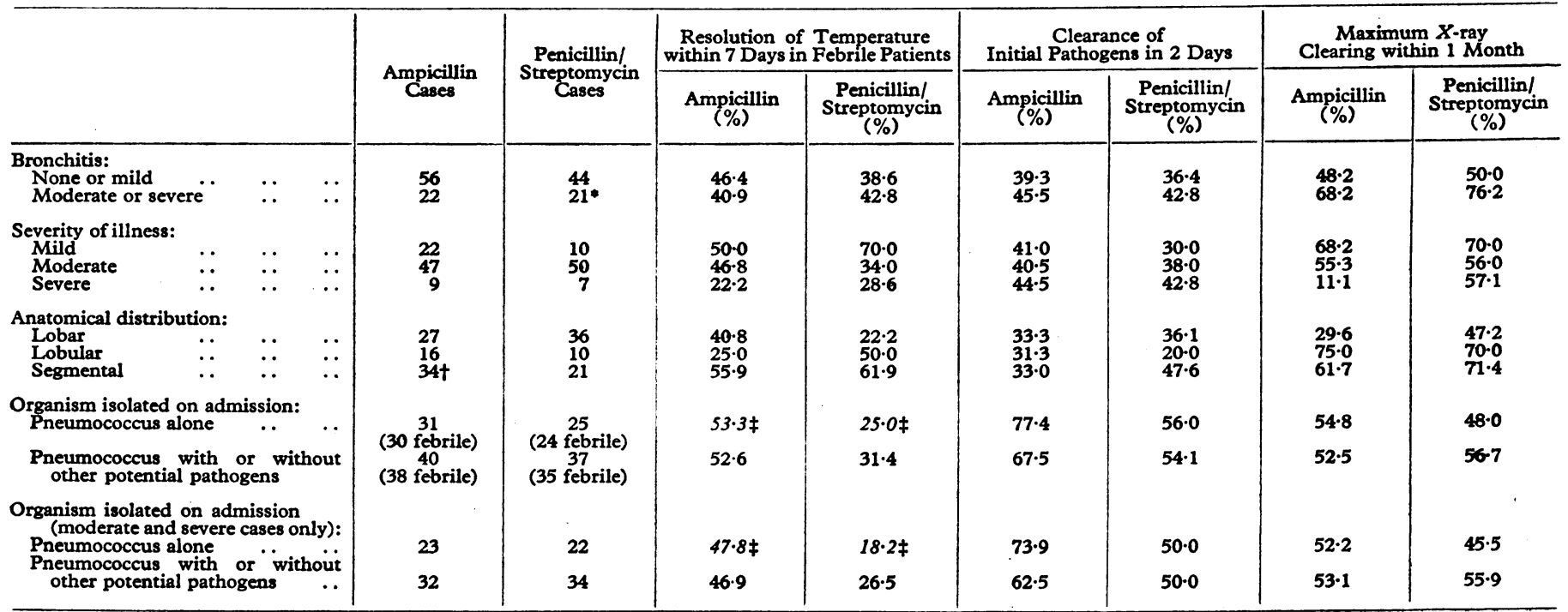


nevertheless be treated with some reserve, as it does not hold true when all cases of pneumococcal pneumonia are considered -that is, including those in which there is a second infecting organism (usually $H$. influenzae). The difference between the two treatment groups in favour of ampicillin is then not significant $\left(\chi^{2}=1.7 ; \mathrm{P}<0.2\right)$.
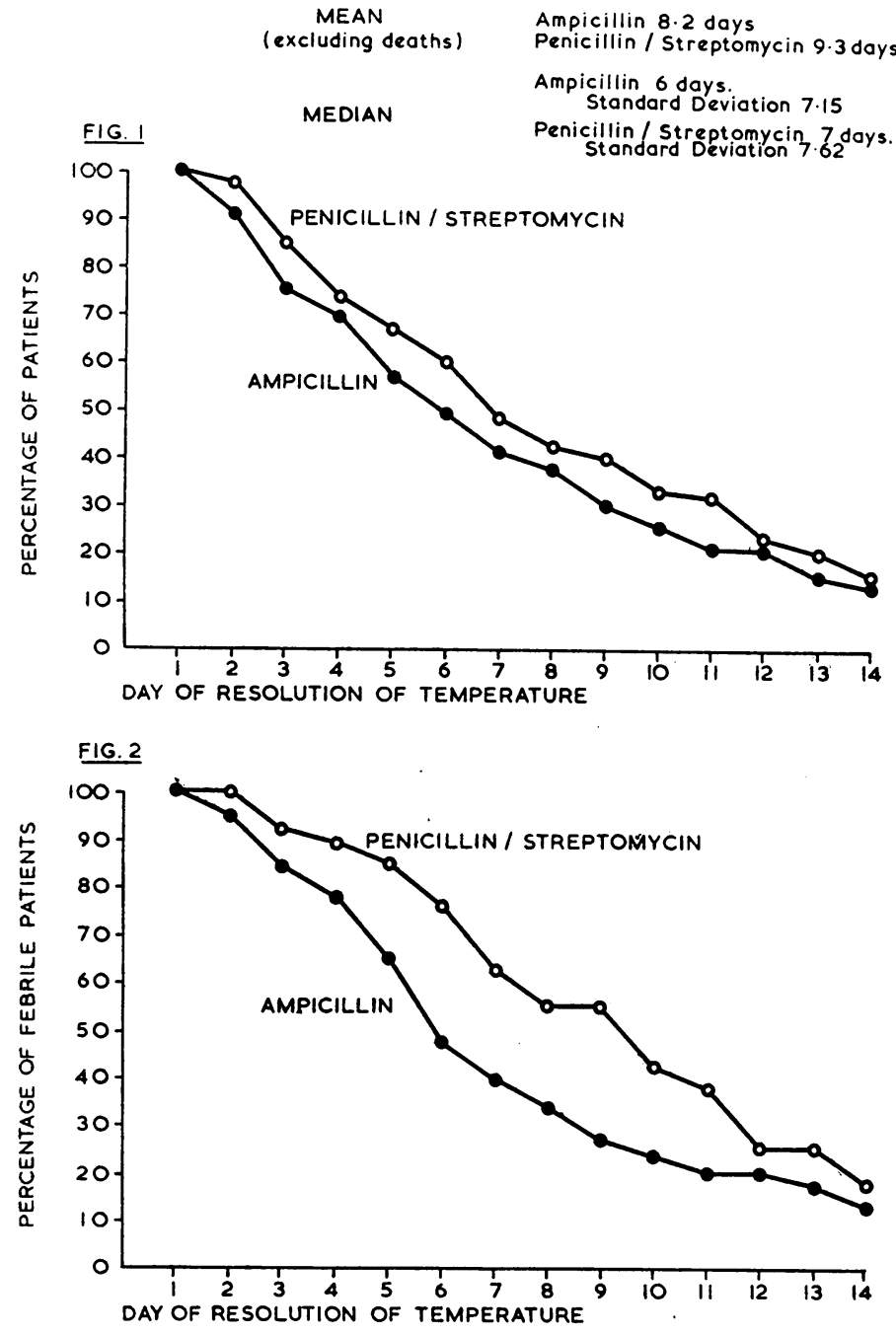

FIg. 1.- Resolution of temperature in all febrile patients. FIG. 2.-Resolution of temperature in febrile patients in whom pneumococcus alone was isolated.

\section{Resistance of the Organism to Drug in Use}

The resistance of the organisms to the drugs in use did not appear to influence the results. In a few cases in both groups the organism isolated and thought to be causing the pneumonia was resistant by laboratory tests, but in none of these cases was there any undue delay in the clearing of the pneumonia.

\section{Hypersensitivity}

There were five cases of skin rash due to hypersensitivity to the drug used-three due to ampicillin and two to penicillin. In all these cases treatment was stopped. Apart from these hypersensitivity reactions no unpleasant side-effects were noted in either of the treatment groups.

\section{Expense}

Very little difference has been observed in the results of treatment in the two groups. That being so, it is relevant to consider the economics of prescribing. The price of ampicillin has fallen during the course of this trial from $8 \mathrm{~s}$. to $6 \mathrm{~s}$. $3 \mathrm{~d}$. per gramme. With increasing use the price may decrease further. In June 1965 a 14-day course of ampicillin cost $£ 47 \mathrm{~s}$. 6d. A 14-day course of penicillin and streptomycin in the doses used in this trial cost $£ 219$ s. 6d. Whereas administration of these drugs in hospital costs very little, injections twice daily in domiciliary practice are expensive in terms of time, whether they are given by doctor or nurse, and this must be allowed for in considering the cost of treatment. This would reduce and possibly even abolish the present difference in cost of the two régimes studied. Because of the difficulty of giving injections at 12-hourly intervals in domiciliary practice it may be more usual to give a few injections at the beginning of the illness and then to change to oral penicillin. On our data we cannot say whether or not this would be as successful, but the few cases treated in this series by oral penicillin in the second week appeared to require a longer course of treatment than average.

\section{Discussion}

There have been previous controlled trials of ampicillin in the treatment of bronchitis (Ayliffe and Pride, 1962; Grant et al., 1962 ; Howells and Tyler, 1963 ; Elmes et al., 1965), but so far as we can determine no such trial in pneumonia has been published, though individual cases have been reported (Bunn et al., 1962 ; Trafford et al., 1962 ; General Practitioner Clinical Trials, 1963 ; Holloway et al., 1963).

The results of this investigation have shown that ampicillin, even in the small dosage used, has been as effective in the treatment of pneumonia as the combined administration of penicillin and streptomycin. The incidence of death was the same in the two groups. No significant difference emerged between the groups as a whole in respect of duration of treatment, resolution of temperature, clearance of the initial pathogen, or the achievement of maximum radiological clearing. But in relating these criteria of success to different types of cases it emerged that in patients in whom the infection was due to the pneumococcus alone ampicillin showed a significant advantage in the speed at which the patient became afebrile. Admittedly a larger number of patients receiving ampicillin were only mildly ill, but if these mild cases were excluded from the analysis the results on the moderately and severely ill patients still favoured ampicillin, and these results were still significant. In spite of this, it could be that the better results were due not so much to an inherent superiority of ampicillin but rather to the advantages of six-hourly administration over the 12-hourly one used for penicillin and streptomycin. It would be interesting to know if this difference was abolished by giving the penicillin and streptomycin six-hourly. The dose of ampicillin used in this trial was a low one, but it was the dose advised at the time the trial was designed, and has been shown to be effective. It is interesting to speculate whether an increase to $2 \mathrm{~g}$. a day might produce an even more rapid resolution of the pneumonia.

It is accepted that patients desperately ill when first seen would not be suitable for this type of therapy, but in domiciliary practice the advantages of a drug that can be given orally are obvious, and, even at current prices, the extra expense of the ampicillin capsules is probably offset by the time and expense involved in administering drugs by injection outside hospital.

Though the value of tetracycline in the treatment of pneumonia has not been examined in this paper, it may be relevant to point out here that, though it is administered by mouth and as such may be useful in domiciliary practice, it is still a more expensive drug than ampicillin if the dosage required is taken into account. Tetracycline is normally given in doses of 2 g. a day. The cost of a 14-day course given outside 
hospital is $£ 52 \mathrm{~s}$. 8d., which is a little more than a 14-day course of ampicillin in the dosage used in this trial.

It would seem, then, that in ampicillin the physician has a useful addition to his armamentarium for the treatment of pneumonia.

\section{Summary}

A controlled trial was carried out to compare the use of ampicillin with a combination of penicillin and streptomycin in the treatment of pneumonia. Seventy-eight patients were allocated to the ampicillin group, in which the régime was oral ampicillin $250 \mathrm{mg}$. six-hourly for 7 or 14 days. Sixtyseven were allocated to the penicillin/streptomycin group, in which the régime required injections of penicillin 1 mega unit b.d. for 7 or 14 days with streptomycin $1 \mathrm{~g}$. b.d. for the first seven days. The treatment groups were comparable, and the results of treatment were similar in the two groups. The only difference of statistical significance was that a larger proportion of cases infected with pneumococci alone became afebrile within one week when treated with ampicillin than when treated with penicillin and streptomycin. Ampicillin appears to be at least as effective as penicillin and streptomycin even in the comparatively small doses used in this trial. There would appear to be an advantage in domiciliary practice in using a drug that can be given by mouth, and if an allowance is made for the cost of giving injections there is little difference in the expense.

Our thanks are due to the following doctors who played a major part in the day-to-day conduct of the trial: Drs. S. I. Ahmed, C. Aitken, A. J. Akhtar, Isobel M. E. Anderson, D. Bell, Kathleen R. M. Brooks, K. A. Buchan, S. Cameron, J. L.
Christie, G. K. Crompton, T. E. Escott, P. Graham, E. Ruth Gray, W. Gray, J. G. Guy, F. F. Hafez, A. C. Harvey, M. D. Haynes, Barbara G. Head, Joyce M. Hendry, C. Hope, Elinor O. S. Hope, Sylvia Jones, A. B. Kay, W. P. U. Kennedy, T. S. Kerr, W. J. H. Leckie, D. O. Lewis, J. Macnamara, T. Middlemass, W. D. Murray, P. L. Pigott, H. Polson, Janet C. Potter, K. D. G. Reid, B. Ritchie, M. Schonell, B. Stack, Sadie D. Walsh, J. B. Wilson, A. Zealley; and to Sisters Black, Boylan, Ferguson, Geekie, Goodwin, Griffiths, McLeod, McSween, Nichol, O'Malley, and Simpson. We are also grateful to Mr. B. A. Burns, Miss Joy E. Chowdray, Mr. J. A. W. Sutherland, Mr. W. J. Webber, and to the many other technicians of the Wellcome Laboratory, City Hospital, and the Central Microbiological Laboratories for technical assistance.

We are particularly grateful to Miss $\mathbf{M}$. C. Drummond, who acted as co-ordinating secretary of the trial. The work forms part of a series of investigations supported by the Wellcome Trust, the Scottish Hospital Endowments Research Trust, the Royal Victoria Hospital Tuberculosis Trust, and the Chest and Heart Association. The ampicillin was generously donated by Beecham Research Laboratories Ltd. through the courtesy of Dr. E. T. Knudsen (Medical Director).

\section{REFERENCES}

Ayliffe, G. A. J., and Pride, N. B. (1962). Brit. med. F., 2, 1641

Bunn, P., O'Brien J., Bentley, D. and Hayman, H. (1962). Antimicrob.

Agents and Chemother., p. 323 .
Elmes, P. C., King, T. K. C., Langland, J. H. M., Mackay, J. A., Wallace, W. F. M., Wade, O. L., and Wilson, T. S. (1965). ' Brit. med. Ұ., 2,904

General Practitioner Clinical Trials (1963). Practitioner, 191, 356.

Grant, I. W. B., Douglas, A. C., and Murray, W. D. (1962). Brit. med. f., 2,482 .

Holloway, W. J., Peters, C. D., and Scott, E. G. (1963). Antimicrob. Agents and Chemother., p. 314.

Howells, C. H., and Tyler, L. E. (1963). Brit. F. clin. Pract., 17, 321.

Trafford, J. A. P., Maclaren, D. M., Lillicrap, D. A., Barnes, R. D. S., Houston, J. C.., and Knox, R. (1962). Lancet, 1, 987.

\title{
Gastric Aspiration and Lavage in Acute Poisoning
}

\author{
HENRY MATTHEW,* M.B., F.R.C.P.ED. ; T. F. MACKINTOSH,* M.B., D.C.H., M.R.C.P.ED. \\ S. L. TOMPSETT, $\dagger$ D.SC., PH.D., F.R.I.C. ; JEAN C. CAMERON, $\dagger$ A.I.M.L.T.
}

Brit. med. F., 1966, 1, 1333-1337

The management of patients who have ingested poison either accidentally or in attempting suicide presents many problems, not the least of which is whether the stomach should be evacuated. Because of the increasing number of such patients (Ministry of Health, 1962), these problems in management take up much of the time of general practitioners and hospital doctors.

There is no doubt that in certain types of poisoning gastric aspiration and lavage is positively dangerous; this form of therapy therefore has no part to play in the management of poisoning by kerosene and other petroleum distillates (Capel and Gardner, 1960 ; Cachia and Fenech, 1964 ; Baldachin and Melmed, 1964). It should be undertaken with the greatest of care when corrosive poisons have been swallowed, also in alcoholics, in the elderly and very young, and in patients who have undergone gastric surgery. However, the majority of poisoned adults seen in hospital in this country do not fall into these limited groups, and, surprisingly, the advice offered by various authors is contradictory regarding the value of

\footnotetext{
* Poisoning Treatment Centre, Royal Infirmary, Edinburgh.

t University Department of Clinical Chemistry, Royal Infirmary, Edinburgh.
}

gastric aspiration and lavage, particularly in respect of barbiturates, which are by far the commonest drugs taken.

Harstad et al. (1942) demonstrated that even shortly after barbiturate had been ingested little could be recovered by gastric aspiration and lavage. This fact, along with their demonstration that particles of charcoal added to the lavage fluid could later be found in the pulmonary tissues of patients who died, led to the abandonment of gastric lavage by Danish workers (Louw, 1958) and to the use of gastric aspiration alone, without lavage, if it was known that the drug had been taken within one hour previously (Clemmesen and Nilsson, 1961). However, Wright (1955) found that in three out of six cases treated within four hours of ingestion appreciable quantities-that is, over $200 \mathrm{mg}$. of barbiturate-were recovered from the gastric washings. In the six patients treated more than four hours after ingestion no barbiturate was recovered.

Allan (1961), recording his experience with 68 patients, stated that "in most cases of barbiturate overdose, stomach lavage removes only small quantities of ingested barbiturate." $\mathrm{He}$ stressed the hazards associated with the procedure, especially in inexperienced hands, when the patient was semi- 